\title{
Use of a species-rich and degraded tropical estuary by Elasmobranchs
}

\author{
Fernanda Gonçalves-Silva ${ }^{1, *}$, Marcelo Vianna ${ }^{1}$
}

${ }^{1}$ Universidade Federal do Rio de Janeiro

(Av. Carlos Chagas Filho, 373 - Cidade Universitária - 21941-902 - Rio de Janeiro - Brazil)

*Corresponding author: fernanda.mgs@hotmail.com

Conservation of elasmobranch populations is a priority, as $31 \%$ of shark and ray species have already gone extinct and 64 threatened species need new or more stringent protections, including improvement in fisheries management. One of the main reasons for this critical condition is that many species inhabit coastal areas, including estuaries, and are directly affected by the degradation of their habitat (Martin, 2005; Davidson et al., 2016, Rodrigues et al., 2018). Estuaries are among the most resilient ecosystems and provide adequate conditions for nursery, feeding, growth, sheltering and breeding of elasmobranch populations (Maes et al., 2004; Farrugia et al., 2001), but many estuarine systems worldwide are heavily polluted. This study aimed to contribute to the knowledge of elasmobranchs in an impacted tropical estuary in southeastern Brazil, Guanabara Bay, Rio de Janeiro, determining the time of year and the sites with the highest incidence of these animals.

From the mouth (lower estuary) to the innermost areas (upper estuary) of Guanabara Bay a natural and anthropic hydrological gradient exists, which is driven by discharge from domestic and industrial pollution, affecting the quality of water, sediments and biota (Silva-Junior et al., 2016). The entrance of the bay (area 4) has a strong marine influence on the hydrological and sedimentary characteristics, with high salinities and fine sediments. In the central channel (area 3 ), where depths of 30 meters are found, hydrodynamics is intensified by the influence of a salt wedge associated with tidal currents. The upper part of the estuary (areas 1 and 2), mainly on the Northwest and West sections where depths are low and the circulation strict, the less saline and eutrophic waters are found. The Northeast (area 2) and East regions are less polluted thanks to their proximity with the conservation unit of the Guapimirim basin. However, a strong population growth has been recorded around those areas in recent decades

Submitted on: 19/June/2018

Approved on: 24/November/2018

http://dx.doi.org/10.1590/S1679-87592018020106604
(Ribeiro and Kjerfve, 2002; Silva-Júnior et al., 2016). The dry season occurs in winter (June to August) when the water column is more homogeneous, and the rainy season is in summer (December to March), when vertical stratification is common (Valentin et al. 1999; Figueiredo Jr and Fernandez, 2012).

Sampling areas were determined with the aim to depict the above-mentioned environmental conditions (Figure 1). Detailed information on each sampling site is available in Silva-Junior et al. (2016) and sediment data are available in Corrêa and Vianna (2016). Sampling was conducted (IBAMA/Brazilian Institute of Environment and Water Resources - Permit No. 055, 12/05/2005) in two phases. The first (Phase I) consisted of biweekly surveys from July 2005 through June 2007, in five areas, with two tows per area, covering the entire estuarine gradient. Areas 1 and 2 were in the upper estuary, area 5 in the middle, and Areas 3 and 4 in the lower estuary. The second (Phase II) sampling scheme was performed monthly from November 2012 through March 2015 in Areas 3 and 5 only, with three tows each (Figure 1). Samples were collected using the same trawl net and the same fishing vessel, operating at an average trawling speed of 1.5 knots. The net employed was 7-m long with a 14-m ground rope, and the mesh size was $18 \mathrm{~mm}$ between adjacent knots. This methodology collected an assortment of demersal animals. The fish caught were sacrificed by placing them on ice and then transported to the laboratory, where they were frozen. Elasmobranchs were identified with appropriate literature (e.g. Gomes et al., 2010). Each specimen was measured (total length $-L_{\mathrm{T}}$ for Rhinobatidae, and disc width - $W_{\mathrm{D}}$ for Dasyatidae and Gymnuridae) in centimeters $(\mathrm{cm})$ and their total mass measured as grams ( $\mathrm{g}$ ). The sex and stage of maturity (juveniles or adults) for males were based on shape and rigidity of clasper.

A cumulative species-occurrence curve was used to determine whether the sampling effort was representative of the elasmobranch species inventory in the bay. The density and biomass of elasmobranchs per area trawled $\left(A_{\mathrm{T}}\right)$ 


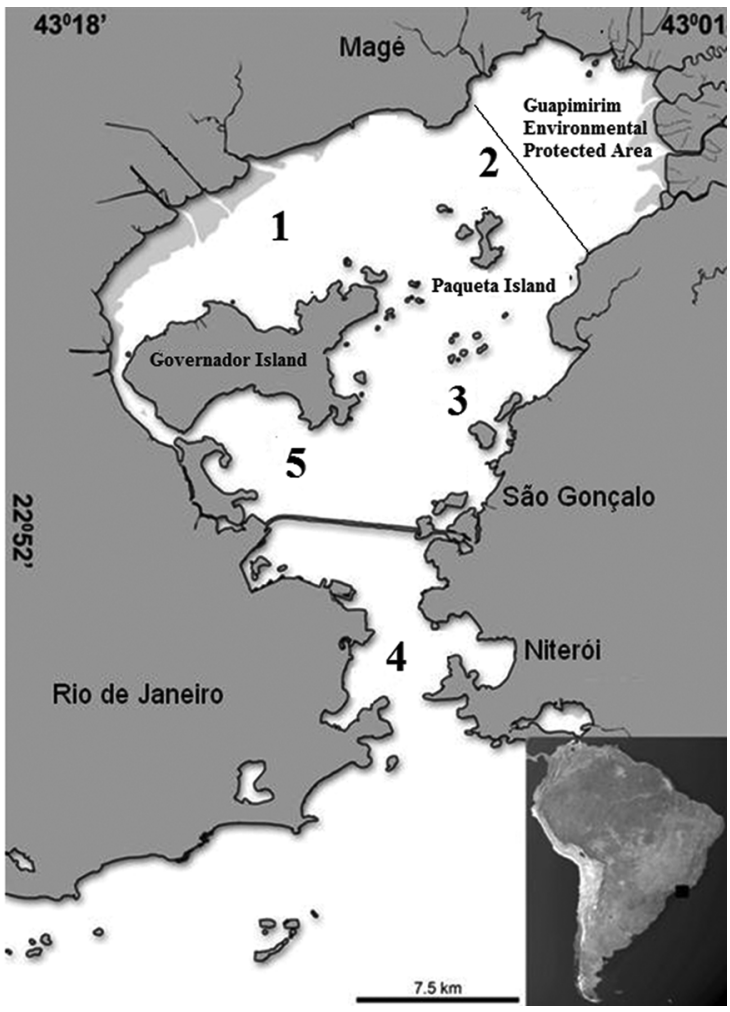

Figure 1. Guanabara Bay showing locations of samples taken from July 2005 through June 2007 (Phase I) and from November 2012 through March 2015 (Phase II - only points 3 and 5), Rio de Janeiro, Brazil, southwestern Atlantic. 1- Duque de Caxias, 2- Paquetá Island, 3- Central Channel, 4- Botafogo/Jurujuba, 5- Governador Island.

were calculated using the equation, $A_{\mathrm{T}}=D h X_{2}$, where $D$ is the distance traveled by the net in kilometers $(\mathrm{km}), h$ is the length of the head rope $(\mathrm{km})$ and $X_{2}$ is a constant that represents the fraction of the length of the head rope $(h$ $X_{2}$ ), referring to the width of the trajectory swept by the net mouth (Sparre and Venema, 1997). The distance traveled $(D)$ corresponds to the velocity of the tow $(1.5$ knots $=$ $2.78 \mathrm{~km} \mathrm{~h}^{-1}$ ) multiplied by the length of time taken by the trawl $(0.5 \mathrm{~h})$. The head rope measured $0.015 \mathrm{~km}$ and the value of the constant $X_{2}$ was 0.5 (Barletta et al., 2005). The catch per unit area trawled was used to calculate the density (ind $\mathrm{km}^{-2}$ ) and biomass $\left(\mathrm{g} \mathrm{km}^{-2}\right)$, dividing the number and biomass of the individuals caught in each trawl by the area swept $\left(A_{\mathrm{T}}\right)$. The use of the analysis by area is necessary from the moment that different sampling efforts were carried out in the different phases, allowing to compare the catches. The individuals sampled were grouped by time and site, in order to identify possible temporal or spatial patterns of occurrence.

To determine spatial and temporal relationships in the composition and abundance of the species, nonparametric multivariate analyses were employed, using the program PRIMER version 6.0 (Clarke and Gorley, 2006). The similarity matrix between sampling areas and time (Phase I) was constructed using the Bray-Curtis coefficient, after applying the square root-transformation. Based on the matrix, a cluster analysis was performed by the UPGMA (Unweighted Pair Group Method with Arithmetic Mean) method. An ordination analysis (for the sampling areas in phase I) was used to determine whether the species composition varied along the estuary, through nMDS (nonmetric multidimensional scaling) (Zar, 1999).

Ninety-seven elasmobranchs were caught (Table 1), 69 in the first and 28 in the second phase. Six species belonging to three families, Dasyatidae, Gymnuridae and Rhinobatidae were recorded in phase I, the butterfly ray G. altavela $(\mathrm{n}=38)$, lesser guitarfish Zapteryx brevirostris (Müller and Henle, 1841) (n=17), stingray Dasyatis hypostigma (Santos and Carvalho, 2004) ( $\mathrm{n}=7)$, Brazilian guitarfish Pseudobatos horkelii (Müller and Henle, 1841) ( $\mathrm{n}=4)$, southern guitarfish Pseudobatos percellens (Walbaum, 1792) $(\mathrm{n}=2)$ and longnose stingray Hypanus guttatus (Bloch and Schneider, 1801) $(\mathrm{n}=1)$. In phase II, only G. altavela $(\mathrm{n}=26)$ and $H$. guttatus $(\mathrm{n}=2)$ occurred. Analysis of the cumulative catch indicated that the sampling effort was sufficient to carry out the inventory of demersal elasmobranchs in the estuary, and no additional species were recorded after the ninth bimester (Figure 2). The effort and the spatial coverage were reduced in Phase II, this could be related to the absence of new catches after the ninth bimester.

Seasonally, in Phase I, the density was highest at the end of summer and beginning of autumn (March-April), in both 2006 and 2007 (30.9 ind $\mathrm{km}^{-2}$ ); and the biomass was highest in March-April $2006\left(39,052.4 \mathrm{~g} \mathrm{~km}^{-2}\right)$. Zapteryx brevirostris and G. altavela were the main contributors in these periods in both years. In phase II, highest density $\left(63.7\right.$ ind $\left.\mathrm{km}^{-2}\right)$ and biomass $(213,706.3 \mathrm{~g}$ $\mathrm{km}^{-2}$ ) were recorded in late spring (November-December 2012) (Table 2). Including both phases, $73 \%$ of the elasmobranchs were caught in the November-April period. The cluster analysis for Phase I (Figure 3) showed that temporally the samples formed two main groups according the abundance: ( 1 - blue) when 6 or more individuals were caught, mostly from November through April; and (2 - red) when fewer specimens were sampled, between May and October.

Spatially, in the first phase of the study, most elasmobranchs were caught in the lower estuary $(63.7 \%)$, 
Table 1. Species of elasmobranchs caught and recorded in Guanabara Bay, Brazil, southwestern Atlantic. Status of the species in the IUCN Red List in the world, and in Brazil (ICMBio, 2014), total number (N), disc width (WD) or total length (LT*), mass, relative frequency (\%) (Phase I, July 2005 - June 2007 and Phase II, November 2012 - March 2015). DD - Data deficient, VU - Vulnerable, NT - Near threatened, CR - Critically endangered.

\begin{tabular}{|c|c|c|c|c|c|c|c|c|c|}
\hline \multirow[b]{2}{*}{ Species } & \multirow{2}{*}{$\begin{array}{c}\text { IUCN } \\
\text { Red list }\end{array}$} & \multirow[t]{2}{*}{ ICMBio } & \multirow[b]{2}{*}{$\mathrm{N}$} & \multirow[b]{2}{*}{$\%$} & \multicolumn{2}{|c|}{$W_{\mathrm{D}} / L_{\mathrm{T}}(\mathrm{cm})$} & \multicolumn{2}{|c|}{ Mass (g) } & \multirow{2}{*}{ Record } \\
\hline & & & & & Min. & Máx. & Min. & Máx. & \\
\hline Dasyatis hypostigma & $D D$ & - & 7 & 7.2 & 15.3 & 32.8 & 109 & 1347 & captured \\
\hline Gymnura altavela & $V U$ & $C R$ & 64 & 66 & 30.3 & 108.0 & 181 & 11000 & captured \\
\hline Hypanus guttatus & $D D$ & - & 3 & 3.1 & 18.5 & 20.8 & 160 & 270 & captured \\
\hline Pseudobatos horkelii* & $C R$ & $C R$ & 4 & 4.1 & 24.0 & 115.0 & 44 & 7200 & captured \\
\hline Pseudobatos percellens* & $N T$ & - & 2 & 2.1 & 31.6 & 93.2 & 101 & 3263 & captured \\
\hline Zapteryx brevirostris* & $V U$ & $V U$ & 17 & 17.5 & 14.0 & 48.6 & 160 & 906 & captured \\
\hline TOTAL & & & 97 & 100 & & & & & \\
\hline Rhinoptera bonasus & & & & & & & & & literature \\
\hline Pristis perotteti & & & & & & & & & literature \\
\hline Sphyrna tiburo & & & & & & & & & literature \\
\hline Sphyrna zygaena & & & & & & & & & literature \\
\hline Aetobatus narinari & & & & & & & & & probability \\
\hline Atlantoraja castelnaui & & & & & & & & & probability \\
\hline Narcine brasiliensis & & & & & & & & & probability \\
\hline
\end{tabular}

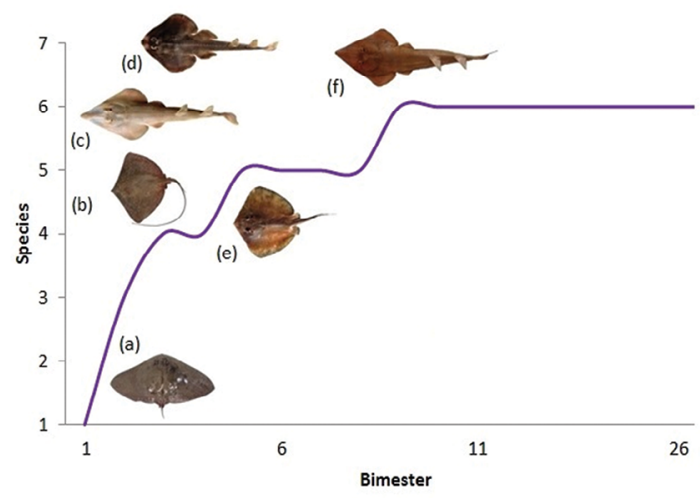

Figure 2. Cumulative sampling curve of elasmobranchs caught bimonthly (Phase I: July 2005 - June 2007 and Phase II: November 2012 - March 2015) in Guanabara Bay, southwestern Atlantic. (a) Gymnura altavela, (b) Dasyatis hypostigma, (c) Pseudobatos horkelii, (d) Zapteryx brevirostris, (e) Hypanus guttatus (f) Pseudobatos percellens.

with $80 \%$ of the catches in area 4 , which had the highest diversity and $83 \%$ of the species. Zapteryx brevirostris dominated in this area, comprising $48 \%$ of the catches. The highest density was also observed in area 4 (33.7 ind $\left.\mathrm{km}^{-2}\right)$, and the lowest in area $2\left(2\right.$ ind $\left.\mathrm{km}^{-2}\right)$. In the second phase, elasmobranchs were found only in the middle estuary (area 5), with a density of 29.6 ind $\mathrm{km}^{-2}$. In the lower estuary (area 3) no elasmobranchs were sampled (Figure 4a). Cluster analysis of the catch in Phase I showed that area 4 was highly distinct from the other sampling locations. This result was related to the higher elasmobranch abundance in area 4 , in addition to the occurrence of $Z$. brevirostris, which was restricted to this area. In fact, most elasmobranch species were recorded in area 4 . Other similar groups were areas 5 and 1, probably related to the presence of $G$. altavela (Figure 4b).

The conservation of elasmobranchs is important as these fish have long life cycles and play important roles at high trophic levels (Abilhoa et al., 2007; Dulvy et al., 2017; Gonçalves-Silva and Vianna, 2018). Elasmobranch bycatch in fisheries focused on crustaceans and teleosts is a major problem, which in most cases is not documented in fishery statistics (Stevens et al., 2000; Francis et al., 2001; Rodrigues et al., 2018). In addition, ray fisheries have always been neglected in Brazil and ray meat consumption remains frequently unnoticed as consumers are not entirely aware of their fish diet composition (Bornatowski et al., 2017). Two out of six species sampled in this study (D. hypostigma and H. guttatus) are deficiently studied and the remainder species are in a threatened state, with the most serious being $P$. horkelli, classified as critically endangered in the IUCN red list (IUCN, 2018). In Brazil G. altavela, P. horkelii and $Z$. brevirostris are endangered species ICMbio (2014) (Table 1), and Rosenfelder et al. (2012) have reported $G$. altavela and $Z$. brevirostris, from Guanabara Bay, with a high degree of contamination. 
Table 2. Species, number of individuals of elasmobrachs $(\mathrm{N})$, density (ind $\left.\mathrm{km}^{-2}\right)$ and biomass $\left(\mathrm{g} \mathrm{km}^{-2}\right)$ per area trawled sampled in Guanabara Bay, Brazil, southwestern Atlantic (Phase I*, July 2005 - June 2007 and Phase II, November 2012 March 2015). H. gut, Hypanus guttatus; D. hyp, D. hypostigma; G. alt, Gymnura altavela; P. hor, Pseudobatos horkelii; P. per, P. percellens; Z. bre, Zapteryx brevirostris.

\begin{tabular}{|c|c|c|c|c|c|c|c|c|c|c|}
\hline & & H. gut & D.hyp & G. alt & P. hor & P.per & Z. bre & $N$ & Ind $\mathrm{km}^{-2}$ & $\mathrm{~g} \mathrm{~km}^{-2}$ \\
\hline \multirow[t]{3}{*}{$2005^{*}$} & Jul - Aug & & & 3 & & & & 3 & 7.1 & 5481.0 \\
\hline & Sep - Oct & & 2 & 3 & 1 & & & 6 & 14.3 & 26547.6 \\
\hline & Nov- Dec & & 2 & 3 & 1 & & 1 & 7 & 16.7 & 6378.6 \\
\hline \multirow[t]{6}{*}{$2006 *$} & Jan - Feb & & & 1 & & & 1 & 2 & 4.8 & 2395.2 \\
\hline & Mar - Apr & 1 & 3 & 4 & 1 & & 4 & 13 & 30.9 & 39052.4 \\
\hline & May - Jun & & & 2 & & & 1 & 3 & 7.2 & 13223.8 \\
\hline & Jul - Aug & & & 3 & & & & 3 & 7.1 & 25285.7 \\
\hline & Sep - Oct & & & 1 & & & 1 & 2 & 4.8 & 8740.5 \\
\hline & Nov - Dec & & & 4 & & 1 & & 5 & 11.9 & 19111.9 \\
\hline \multirow[t]{3}{*}{$2007 *$} & Jan - Feb & & & 7 & & & 3 & 10 & 23.8 & 25247.6 \\
\hline & Mar - Apr & & & 5 & 1 & 1 & 6 & 13 & 30.9 & 32447.6 \\
\hline & May - Jun & & & 2 & & & & 2 & 4.8 & 14750.0 \\
\hline 2012 & Nov - Dec & & & 8 & & & & 8 & 63.7 & 213706.3 \\
\hline \multirow[t]{6}{*}{2013} & Jan - Fev & & & 4 & & & & 4 & 31.8 & 83968.3 \\
\hline & Mar - Apr & & & 1 & & & & 1 & 7.9 & 6349.2 \\
\hline & May - Jun & 1 & & 3 & & & & 4 & 31.8 & 55952.4 \\
\hline & Jul - Aug & 1 & & 1 & & & & 2 & 15.9 & 15000.0 \\
\hline & Sep - Oct & & & 1 & & & & 1 & 7.9 & 4761.9 \\
\hline & Nov-Dec & & & 1 & & & & 1 & 7.9 & 5396.8 \\
\hline \multirow[t]{6}{*}{2014} & Jan-Fev & & & & & & & 0 & - & - \\
\hline & Mar-Apr & & & 2 & & & & 2 & 15.9 & 44285.7 \\
\hline & May-Jun & & & & & & & 0 & - & - \\
\hline & Jul-Aug & & & & & & & 0 & - & - \\
\hline & Sep-Oct & & & & & & & 0 & - & - \\
\hline & Nov-Dec & & & 2 & & & & 2 & 15.9 & 92381.0 \\
\hline \multirow[t]{2}{*}{2015} & Jan-Feb & & & 2 & & & & 2 & 15.9 & 13095.2 \\
\hline & Mar-Apr & & & 1 & & & & 1 & 7.9 & 5714.3 \\
\hline
\end{tabular}

The review by Vianna et al. (2012) listed five species of elasmobranchs in Guanabara Bay. Four of those were caught in this study; the only exception was Rhinoptera bonasus (Mitchill, 1815). Vianna et al. (2012) compiled studies using different types of gear sampling throughout the water column. Probably $R$. bonasus was not captured in this study due to its benthopelagic habit (Froese and Pauly, 2018). In a publication of endangered species of
Rio de Janeiro, Pristis perotteti (Müller and Henle, 1841), Sphyrna tiburo (Linnaeus, 1758) and Sphyrna zygaena (Linnaeus, 1758) were reported for Guanabara Bay, but are possibly extinct locally nowadays (Buckup et al., 2000). However, P. horkelii and P. percellens were recorded here for the first time in the estuary. These species may be visitors in the estuary, since few individuals were caught during the study. In summary, seven species 


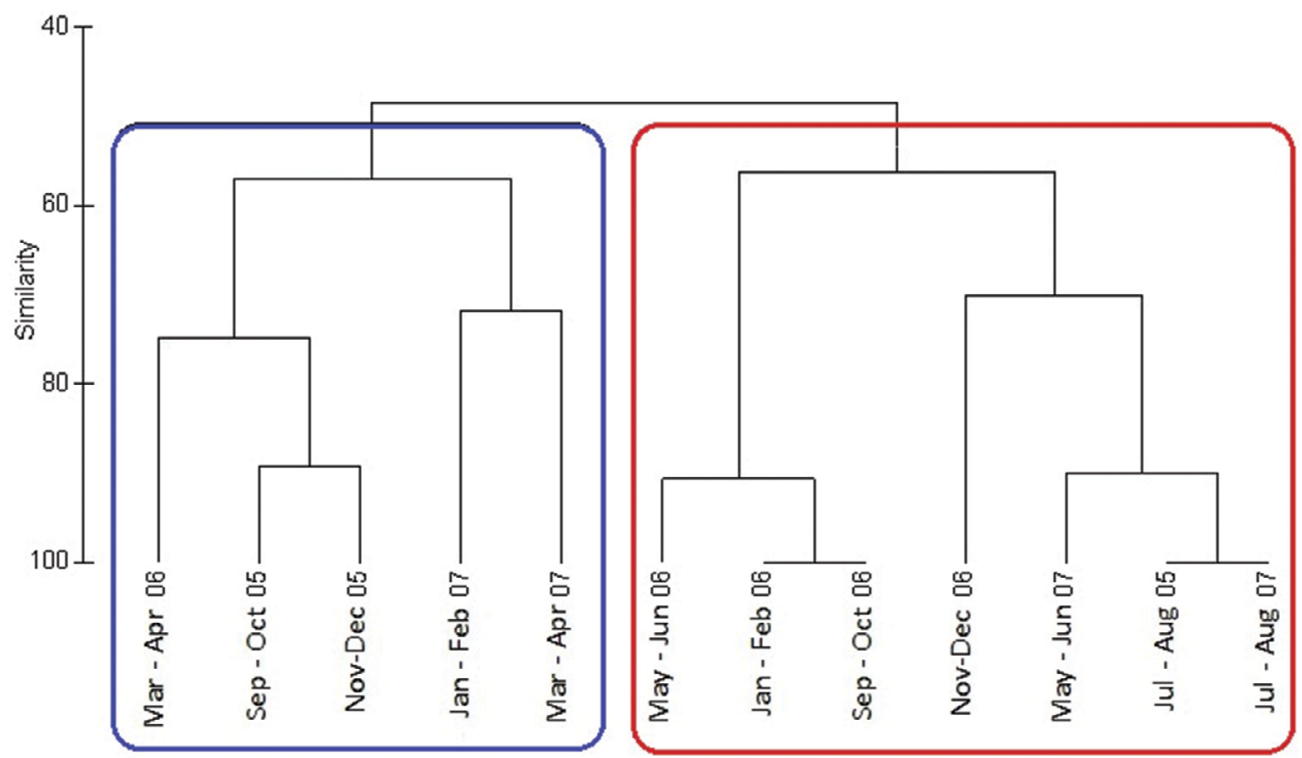

Figure 3. Dendrogram (UPGMA, Bray-Curtis similarity coefficient) for elasmobranchs in Guanabara Bay, southwestern Atlantic (Phase I: July 2005 - June 2007). Two main clusters are delineated, based on bimonthly samples from the first phase of the study. Blue - bimesters when 6 or more individuals were caught. Red - when fewer specimens were sampled.
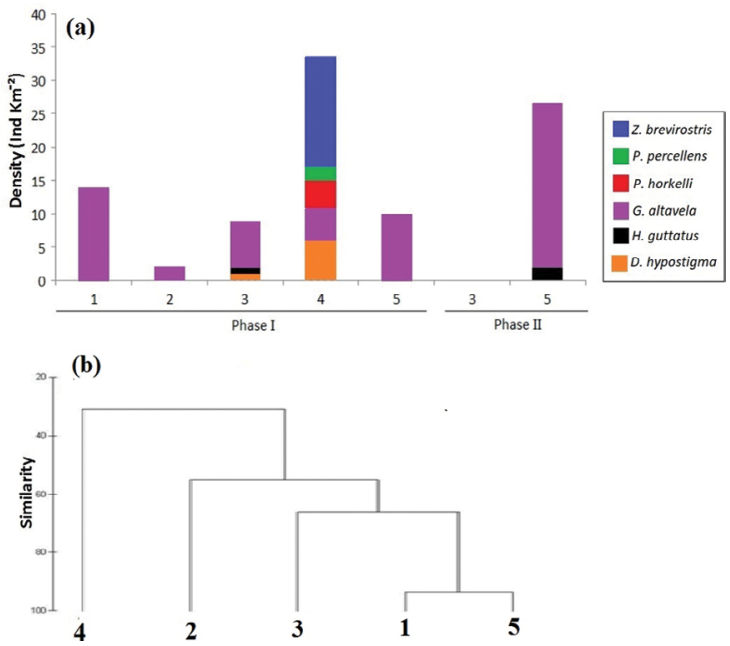

Figure 4. (a) Spatial distribution (ind $\mathrm{km}^{-2}$ ) of elasmobranch species in Guanabara Bay, southwestern Atlantic (Phase I: July 2005 - June 2007 and Phase II: November 2012 - March 2015). (b) Dendrogram (UPGMA, Bray-Curtis similarity coefficient) showing that area 4 was distinct from the other sampling locations, with areas 1 and 5 most similar according to the composition of rays in the estuary of Guanabara Bay, southwestern Atlantic (Phase I: July 2005 - June 2007). 1- Duque de Caxias, 2- Paquetá Island, 3- Central Channel, 4- Botafogo/Jurujuba, 5- Governador Island.

have been identified nowadays in GB, G. altavela, $H$. guttatus, D. hypostigma, R. bonasus, P. horkelii, P. percellens and Z. brevirostris. Other elasmobranch species may also occur, including Aetobatus narinari (Euphrasen, 1790), Atlantoraja castelnaui (Miranda-Ribeiro, 1907) and Narcine brasiliensis (Olfers, 1831), which have been photographed in a coastal area adjacent to the bay (Ricardo Gomes, unpublished data).

Due to its location and extension, Brazil has both tropical (e.g. Chaves and Vendel, 2001; Viana et al., 2010; Dias et al., 2011; Soares et al., 2011) and subtropical estuaries (e.g. Chaves and Corrêa, 1998; Loebman and Vieira, 2005; Moura et al., 2012; Spach et al., 2013) (Table 3). So far, only the Paraguaçu River estuary (Reis-Filho et al., 2010) equals Guanabara Bay in elasmobranch species richness, while six species have been reported for Sepetiba Bay and Todos os Santos Bay (Soares et al., 2011; Dias et al., 2011). The locations with the highest elasmobranch richness in tropical estuaries are found in Thailand and Australia (Blaber et al., 1989; Blaber et al., 1995; Vidthayanon and Premcharoen, 2002). The more open the estuary is to the ocean, the higher the chance that elasmobranch species will occur, since most species are marine (Froese and Pauly, 2018). This is probably the case of the estuary in Thailand surveyed by Vidthayanon and Premcharoen (2002). Other variables may affect such comparison. Basílio et al. (2008) specifically targeted elasmobranchs; but many studies represented general ichthyofaunal surveys, and many did not use appropriate gear for catching demersal species, probably not efficiently sampling this group. The temporal series of collections and the sampling effort are fundamental variables. The longer the duration of a study, the greater the probability of generating new records, and therefore the rarefaction 
Table 3. Survey of the works that obtained elasmobranch captures in Brazil and tropical estuaries in the world, with the fishing gear used and their respective references. Number of elasmobranchs species (N). BotT: Bottom trawl; BeaT: Beach trawl; OttT: Otter trawl; CasN: Cast net; GilN: Gill net; TraM: Manual trawl; FykN: Fyke net; BeaN: Beach seine net; BeamT: Beam trawl; SeiN: Seine net; StaN: Stake net; MesN: Mesh net; PurN: Purse seine net; BaiL: Baited trot line.

\begin{tabular}{lcccc}
\hline Estuary & Local (Coast) & $\mathrm{N}$ & Fishing gear & Reference \\
\hline Sepetiba Bay & Brazil, Southeast & 6 & BotT & Araújo et al.,1998 \\
Todos os Santos Bay & Brazil, Northeast & 6 & more than 11 & Soares et al., 2011; Dias et al., 2011 \\
Curu River Estuary & Brazil, Northeast & 5 & CasN, GilN & Basílio et al.,2008 \\
Paraguaçu River Est. & Brazil, Northeast & 7 & TraM, GilN, CasN & Reis-Filho et al.,2010 \\
Caeté Estuary & Brazil, North & 4 & OttT & Barletta et al., 1998; 2005 \\
Pinheiros Bay & Brazil, South & 4 & FykN, BotT & Oliveira-Neto et al.,2008; Schwarz et al., 2006 \\
Guaratuba Bay & Brazil, South & 1 & CasN, BotT, BeaT, GilN & Chaves \& Corrêa, 1998; Chaves \& Vendel, 2001 \\
Vellar Estuary & India, Southeast & 2 & CasN & Murugan et al.,2014 \\
Embley Estuary & Australia, Northern & 22 & GilN, BeamT, StaN, MesN & Blaber et al.,1989 \\
Albatross Bay & Australia, Northern & 17 & GilN, SeiN, Trawl & Blaber et al., 1995 \\
Salomons estuary & Salomons Island & 8 & GilN, SeiN & Blaber \& Milton, 1990 \\
Gulf of Thailand & Thailand & 30 & Review & Vidthayanon \& Premcharoen 2002 \\
Gâmbia Estuary & Africa, West & 4 & PurN & Albaret et al.,2004 \\
Ebrié Lagoon & Africa, West & 1 & PurN & Ecoutin et al.,2005 \\
Tortuguero Estuary & Costa Rica & 1 & GilN, BaiL & Nordlie \& Kelso, 1975
\end{tabular}

curve is important. In Guanabara Bay, the curve stabilized after 18 months of sampling. The longest studies lasted three years (Chaves and Corrêa, 1998; Basílio et al., 2008) and the great majority for approximately one year.

Guanabara Bay is notable for its considerable richness of elasmobranch species compared to other tropical estuaries. This is probably explained by the influence from an annual low-intensity upwelling system in the adjacent coastal ocean. The cold SACW (South Atlantic Central Water) water mass upwells and the northeast winds cause this water mass to drift southwestward, reaching the bay, where the effect on the temperature and nutrients leads to enrichment of the marine biota (e.g. Valentin, 2001). Knowledge of the seasonal and spatial differences in environmental parameters is essential to understand the distribution of organisms in estuaries and forcing factors such as currents and precipitation are drivers of such dynamics (Elliot et al., 2007). The SACW intrudes on the continental shelf in southeastern Brazil mainly between September and April, but the prevailing winds causing upwelling of this water mass are more frequent and stronger between late spring and summer (November to March). Arriving at Guanabara Bay, this oceanic water advances over the bottom, lowering the temperature and improving the water quality (Valentin, 1994). In parallel, during the rainy season (December to April) the monthly mean rainfall exceeds $100 \mathrm{~mm}$, increasing the runoff from the bay's
$4000 \mathrm{~km}^{2}$ drainage basin. Salinities decrease and temperatures increase, with consequent thermohaline stratification of the water column (Silva-Junior et al., 2016). Such seasonality helps to explain why the number of elasmobranch species caught increased from November to April. Notably, Z. brevirostris mostly occurred during the SACW influence.

Spatially, all the species except $G$. altavela occurred in the lower estuary, where $83 \%$ of individuals were caught. The richness at this point is explained by the more favorable environmental conditions, influenced by the ocean waters (Valentin et al., 1999; Ribeiro and Kjerfve, 2002), and the higher diversity and abundance of the benthic fauna, including molluscs, crustaceans, polychaetes and small fish (Santi and Tavares, 2009; Neves et al., 2013), which forms the base of the diet of demersal rays (Viana and Vianna, 2014; Viana et al., 2017). Zapteryx brevirostris was caught only at the bay mouth, probably because of its preference for the marine habitat (Abilhoa et al., 2007; Froese and Pauly, 2018). However, Wosnick and Freire (2013) showed that this species can be euryhaline, although they reached no conclusion as to its tolerance to low salinity, and few studies have reported this ray in estuarine environments.

Gymnura altavela was frequent and abundant in Guanabara Bay and its population was present mainly in the inner areas, which are more sheltered, with less calm 
waters, although influenced by several rivers with a high degree of pollution (Silva-Junior et al., 2016). GonçalvesSilva and Vianna (2018) have shown that this ray probably uses this estuary as nursery ground, mainly because of the large number of young individuals found. Guisande et al. (2013) reported that temperature and bathymetry were the variables with a higher contribution to the variance observed for species richness of batoids and sharks, while the negative effect of anthropogenic factors were also important. Such natural and anthropic influences are important in Guanabara bay.

In summary, elasmobranch species richness and abundance were high in Guanabara Bay, mainly from November to April and at the estuary mouth, influenced by water circulation and rainfall. Environmental degradation in Guanabara bay must be quickly reversed, given the importance of this estuary to endangered species of elasmobranchs.

\section{REFERENCES}

ABILHOA, V., BORNATOWSKI, H. \& FREITAS, M. O. 2007. Some information on reproduction and embryonic development of the lesser guitarfish Zapteryx brevirostris in Southern Brazil. Acta Adriatica, 48, 185-190.

ALBARET, J. J., SIMIER, M., DARBOE, F. S., ECOUTIN, J. M., RAFFRAY, J. \& MORAIS, L. T. 2004. Fish diversity and distribution in the Gambia Estuary, West Africa, in relation to environmental variables. Aquatic Living Resources, 17, 35-46.

BARLETTA, M., BARLETTA-BERGAN, A. \& SAINT-PAUL, U. 1998. Description of the fishery structure in the mangrove dominated region of Bragança (State of Pará, North Brazil). Ecotropica, 4, 41-53.

BARLETTA, M., BARLETTA-BERGAN, A., SAINT-PAUL, U. \& HUBOLD, G. 2005. The role of salinity in structuring the fish assemblages in a tropical estuary. Journal of Fish Biology, 66, 45-72.

BASÍLIO, T. H., FARIA, V. V. \& FURTADO-NETO, M. A. A. 2008. Fauna de Elasmobrânquios no Estuário do Rio Curu, Ceará, Brasil. Arquivo de Ciências do Mar, 41, 65-72.

BLABER, S. J. M. \& MILTON, D. A. 1990. Species composition, community structure and zoogeography of fishes of mangrove estuaries in the Solomon Islands. Marine Biology, 105, 259-267.

BLABER, S. J. M., BREWER, D. T. \& SALINI, J. P. 1989. Species composition and biomasses of fishes in different habitats of a tropical Northern Australian estuary: Their occurrence in the adjoining sea and estuarine dependence. Estuarine, Coastal and Shelf Science, 29, 509-531.

BLABER, S. J. M., BREWER, D. T. \& SALINI, J. P. 1995. Fish communities and the nursery role of the shallow inshore waters of a tropical bay in the Gulf of Carpentaria, Australia. Estuarine, Coastal and Shelf Science, 40, 177-193.

BORNATOWSKI, H., BRAGA, R. R., \& BARRETO, R. P. 2017. Elasmobranchs consumption in Brazil: impacts and consequences. In: ROSSI-SANTOS, M. R., FINKL, C. W. (eds.) Advances in Marine Vertebrate Research in Latin America. Cham: Springer International Publishing, 251-262.
BUCKUP, P. A., NUNAN, G. W., GOMES, U. L., COSTA, W. J. E. M. \& GADIG, O. B. F. 2000. In: Rio de Janeiro 2000. Espécies ameaçadas de extinção do Munícipio do Rio de Janeiro: flora e fauna. Rio de Janeiro: Secretaria Municipal de Meio Ambiente, 54-55.

CHAVES, P. T. C. \& CORRÊA, M. F. M. 1998. Fish faunal composition of the mangrove area of the Guaratuba Bay, Paraná, Brazil. Revista Brasileira de Zoologia, 15, 195-202.

CHAVES, P. T. C. \& VENDEL, A. L. 2001. Nota complementar sobre a composição ictiofaunística da Baía de Guaratuba, Paraná, Brasil. Revista Brasileira de Zoologia, 18, 349-352.

CORRÊA, B. \& VIANNA, M. 2016. Spatial and temporal distribution patterns of the silver mojarra Eucinostomus argenteus (Perciformes: Gerreidae) in a tropical semi-enclosed bay. Journal of Fish Biology, 89, 641-660.

CLARKE, K. R. \& GORLEY, R. N. 2006. PRIMER v6: User Manual/Tutorial. PRIMER-E, Plymouth, UK.

CORTÉS E. 2000. Life history patterns and correlations in sharks. Reviews in Fisheries Science, 8, 299-344.

DAVIDSON, L. N. K., KRAWCHUK, M. A. \& DULVY, N. K. 2016. Why have global shark and ray landings declined: improved management or overfishing? Fish and Fisheries, 17, 438-458.

DIAS, J. F., GONÇALVES, A. M., FERNANDEZ, W. S., SILBIGER, H. L. N., FIADI, C. B. \& SCHMIDT, T. C. S. 2011. Ichthyofauna in an estuary of the Mataripe area, Todos os Santos bay, Bahia, Brazil. Brazilian Journal of Oceanography, 59, 75-95.

DULVY, N. K., FOWLER, S. L., MUSICK, J. A., CAVANAGH, R. D., KYNE P. M., HARRISON, L., CARLSON, J. K. , DAVIDSON, L. N. K., FORDHAM, S. V., FRANCIS, M. P., POLLOOCK C. M., SIMPFENDORFER, C. A., GEORGE H BURGESS, G. H., CARPENTER, K. E., COMPAGNO, L. J. V., EBERT, D. A., GIBSON, C., HEUPEL, M. R., LIVINGSTONE, S. R., SANCIANGCO, J. C., STEVENS, J. D., VALENTI, S. \& WHITE, W. T. 2014. Extinction risk and conservation of the world's sharks and rays. eLife, 3 .

DULVY, N. K., SIMPFENDORFER, C. A., DAVIDSON, L. N. K., FORDHAM, S. V., BRAUTIGAM, A., SANT, G. \& WELCH, D. J. 2017. Challenges and Priorities in shark and ray conservation. Current Biology, 27, R565-R572.

ECOUTIN, J. M., RICHARD, E., SIMIER, M. \& ALBARET, J. J. 2005. Spatial versul temporal patterns in fish assemblages of a tropical estuarine coastal lake: The Ebrié Lagoon (Ivory Coast). Estuarine, Coastal and Shelf Science, 64, 623-635.

ELLIOT, M., WHITFIELD, A. K., POTTER, I. C., BLABER, S. J. M., CYRUS, D. P., NORDLIE, F. G. \& HARRISON, T. D. 2007. The guild approach to categorizing estuarine fish assemblages: a global review. Fish and Fisheries, 8, 241-268.

FARRUGIA, T. J., ESPINOZA. M. \& LOWE, C. G. 2011. Abundance, habitat use and movement patterns of the shovelnose guitarfish (Rhinobatos productus) in a restored southern California estuary. Marine and Freshwater Research, 62, 648-657.

FRANCIS, M. P., GRIGGS, L. H. \& BAIR, S. J. 2001. Pelagic shark bycatch in the New Zealand tuna longline fishery. Marine and Freshwater Research, 52, 165-178.

FIGUEIREDO JR., A. G. \& FERNANDEZ, G. B. 2012. Caracterização Geológica e Física. In: MENICONI, M. F. G, SILVA, T. A, FONSECA, M. L., LIMA, S. O. F., LIMA, E. F. A., LAVRADO, H. P. \& FIGUEIREDO JR., A. G. (eds.) Baía de Guanabara, Sintese do Conhecimento ambiental. Ambiente e Influência antrópica. Rio de Janeiro: Petrobras. 22-40. 
FROESE, R \& PAULY, D. 2018. FishBase. World Wide Web electronic publication [version 06/2018]. Available from: http:// fishbase.org

GOMES, U. L., SIGNORI, C. N., GADIG, O. B. F. \& SANTOS, H. R. S. 2010. Guia para Identificação de Tubarões e Raias do Rio de Janeiro. Rio de Janeiro: Technical Books.

GONÇALVES-SILVA, F. \& VIANNA, M. 2018. Diet and reproductive aspects of the endangered butterfly ray Gymnura altavela raising the discussion of a possible nursery area in a highly impacted environment. Brazilian Journal of Oceanography, 66, 315-324.

GUISANDE, C., PATTI, B., VAAMONDE, A., MANJARRESHERNANDEZ, A., PELAYO-VILLAMIL, P., GARCIAROSELLÓ, E., GONZÁLEZ-DACOSTA, J., HEINE, J. \& GRANADO-LORENCIO, C. 2013. Factors affecting species richness of marine elasmobranchs. Biodiversity and Conservation, 22, 1703-1714.

ICMBIO. 2014. (Instituto Chico Mendes de Conservação da Biodiversidade). Lista das Espécies da Fauna Brasileira Ameaçadas de Extinção [updated 2018 Nov 21]. Available from: http://www.icmbio.gov.br/portal/faunabrasileira/listade-especies

IUCN. 2018. (International Union for Conservation of Nature). The IUCN Red List of Threatened Species. Version 2018-1. 2017 [updated 2018 Nov]. Available from: http://www.iucnredlist.org

MAES, J., VAN DAMME, S., MEIRE, P. \& OLLEVIER, F. 2004. Statistical modeling of seasonal and environmental influences on the population dynamics of an estuarine fish community. Marine Biology, 145, 1033-1042.

MARTIN, R. A. 2005. Conservation of freshwater and euryhaline elasmobranchs: a review. Journal of the Marine Biological Association of the United Kingdom, 85, 1049-1073.

MURUGAN, S., KHAN, S. A., LYLA, P. S., RAJA, S. \& JOHN, B. A. 2014. Spatial and temporal variability in fish diversity of Vellar Estuary (South East Coast of India). Annual Research \& Review in Biology, 4, 2147-2162.

NEVES, R. A. F., ECHEVERRIA, C. A., PESSOA, L. A., PAIVA, P. C., PARANHOS, R. \& VALENTIM, J. L. 2013. Factors influencing spatial patterns of molluscs in a eutrophic tropical bay. Journal of the Marine Biological Association of the United Kingdom, 93, 577-589.

NORDLIE, F. G \& KELSO, D. P. 1975. Trophic relationships in a tropical estuary. Revista de Biologia Tropical, 23, 77-99.

OLIVEIRA- NETO, J. F., SPACH, H. L., SCHWARZ-JUNIOR, R. \& PICHLER, H. A. 2008. Diel variation in fish assemblages in tidal creeks in southern Brazil. Brazilian Journal of Biology, 68, 37-43.

REIS-FILHO, J. A., NUNES, J. A. C. C. \& FERREIRA, A. 2010. Estuarine ichthyofauna of the Paraguaçu River, Todos os Santos Bay, Bahia, Brazil. Biota Neotropica, 10, 301-311.

RIBEIRO, C. H. \& KJERFVE, B. 2002. Anthropogenic influence on the water quality in Guanabara bay, Rio de Janeiro, Brazil. Regional Environmental Change, 3, 13-19.

RODRIGUES, A. F. S., RANGEL, B. S., WOSNICK, N., BORNATOWSKI, H., SANTOS, J. L., MOREIRA, R. G., \& AMORIM, A. F. 2018. Report of Injuries in Batoids Caught in Small-Scale Fisheries: Implications for Management Plans. Oecologia Australis, AO\#16002.
ROSENFELDER, N., LEHNERT, K., KAFFARNIK, S., TORRES, J. P. M., VIANNA, M. \& VETTER, W. 2012. Thorough analysis of polyhalogenated compounds in ray liver samples off the coast of Rio de Janeiro, Brazil. Environmental Science and Pollution Research, 19, 379-389.

SANTI, L. \& TAVARES, M. 2009. Polychaeta assemblange of an impacted estuary, Guanabara bay, Rio de Janeiro, Brazil. Brazilian Journal of Oceanography, 57, 287-303.

SCHWARZ JR, R., FRANCO, A. C. N. P., SPACH, H. L., SANTOS, C., PICHLER, H. A. \& QUEIROZ, G. M. L. N. 2007. Variação da estrutura espacial da ictiofauna demersal capturada com rede de arrasto de porta na Baía dos Pinheiros, PR. Boletim Instituto de Pesca de São Paulo, 33, 157-169.

SPARRE, P. \& VENEMA. S. C. 1997. Introdução à avaliação de mananciais de peixes tropicais. Parte 1: Manual, Fisheries Technical Paper. Roma: FAO. 404 p.

STEVENS, J. D., BONFIL, R., DULVY, N. K. \& WALKER, P. A. 2000. The effects of fishing on sharks, rays, and chimaeras (condrichthyans), and the implications for marine ecosystems. ICES Journal of Marine Science, 57, 476-494.

SILVA JR., D. R., PARANHOS, R. \& VIANNA, M. 2016. Spatial patterns of distribution and the influence of seasonal and abiotic factors on demersal ichthyofauna in an estuarine tropical bay. Journal of Fish Biology, 89, 821-846.

SOARES, L. S. H., LOPEZ, J. P., MUTO, Y. M. \& GIANNINI, R. 2011. Capture fishery in northern Todos os Santos bay, tropical southwestern atlantic, Brazil. Brazilian Journal of Oceanography, 59, 61-74.

VALENTIN, J. L. 1994. A ressurgência fonte de vida dos oceanos. Ciência Hoje, 18, 19-25.

VALENTIN, J. L. 2001. The Cabo Frio upwelling system, Brazil. Coastal Marine Ecosystems of Latin America, 144, 97-105.

VALENTIN, J. L., TENENBAUM, D. R., BONECKER, S. L. C., BONECKER, A. C. T., NOGUEIRA, C. R. \& VILLAC, M. C. 1999. O sistema planctônico da Baía de Guanabara, Síntese de conhecimento. Oecologia Brasiliensis, 7, 35-59.

VIANA, A. F. \& VIANNA, M. 2014. The feeding habits of the eyespot skate Atlantoraja cyclophora (Elasmobranchii: Rajiformes) in southeastern Brazil. Zoologia (Curitiba), 31, 119-125.

VIANA, A. F., VALENTIN, J. L. \& VIANNA, M. 2017. Feeding ecology of elasmobranch species in southeastern Brazil. Neotropical Ichthyology, 15, e160176.

VIANNA, M., ANDRADE-TUBINO, M. F., KEUNECKE, K. A., ANDRADE, A. C., SILVA JUNIOR, D. R., PADULA, V. 2012. Estado Atual de Conhecimento sobre a Ictiofauna. In: MENICONI, M. F. G., SILVA, T. A., FONSECA, M. L., LIMA, S. O. F., LIMA, E. F. A., LAVRADO, H. P., FIGUEIREDO JR., A. G. (eds). Baía de Guanabara, Sintese do Conhecimento ambiental v. 2. Biodiversidade. Rio de Janeiro: Petrobras. 170-195.

VIDTHAYANON, C. \& PREMCHAROEN, S. 2002. The status of estuarine fish diversity in Thailand. Marine Freshwater Research, 53, 471-478.

WOSNICK, N. \& FREIRE, C. A. 2013. Some euryhalinity may be more common than expected in marine elasmobranchs, the example of the South American skate Zapteryx brevirostris (Elasmobranchii, Rajiformes, Rhinobatidae). Comparative Biochemistry and Physiology. Part A, Molecular \& Integrative Physiology, 166, 36-43.

ZAR, J. H. 1999. Biostatistical Analysis. $4^{\text {th }}$ ed. Upper Saddle River: Prentice Hall. 